\title{
OLDER LOW-EFFICIENT BOILERS BROWN COAL-FIRED, GENERATED EMISSIONS AND DIFFUSION OF IMISSIONS
}

\begin{abstract}
At thermooxidizing processes generating energy from natural solid fuels, heat as its main product is accompanied with side products solid waste and emissions, resulting in unfavourable effects on the environment. This contribution deals with the results of measurements and analyses regarding an old-fashioned type boiler unit fired by solid fuel. It showed low efficiency of older brown coal fired boilers currently used in many small companies. All of them generate pollutants - gaseous as well as solid emissions polluting the environment. Thus, they cause environmental damage in spite of their meeting emission and imission limits within their category. The imission value of tar component at low temperature of flue gases in fireplace and short time of flue gas remaining in fireplaces causes the presence of some components over the permissible imission limit.
\end{abstract}

Key words: emissions, imissions, brown coal, solid fuel-fired small-size boilers

\section{Introduction and background}

In spite of significant accomplishments that were achieved in the reduction of emissions and imissions in Slovakia during the last decade, there are still many small and midsize sources of emissions that abundantly contribute to the environmental pollution. It is especially old fired heating equipment fuelled with fossil fuels mainly occurring in villages that are not gas connected, but heated by old boilers fuelled with fossil fuels with the heat capacity up to 2 MWth. According to the legislative statutes [1, 2], small sources of pollution do not have determined exact emission limits. That is why entrepreneurs, mainly physical persons, are not obliged to respect certain rules while building such appliances and are not even fined for the air pollution. Midsize sources with lower capacity - up to 2 MWth have only limited concentrations of sulphur and nitrogen oxides, while sulphur oxides are limited by the concentration of $2500 \mathrm{mg} \cdot \mathrm{m}^{-3}$ only under those circumstances when emission flow of sulphur oxides is above $20 \mathrm{~kg}$ an hour, which is not reached by these kinds of appliances. The emission limit of nitrogen oxides in this category of combustion appliances is $650 \mathrm{mg} \cdot \mathrm{m}^{-3}$, which is difficult to achieve because with this pollutant, the concentration in the combustion products is quantitatively dependent either on the temperature that is measured in the combustion chamber of the boiler, or on the content of fixed organic nitrogen in the fuel. To create nitrogen oxides from the air by oxidation of the airborne nitrogen are, as a rule, needed temperatures over $1100{ }^{\circ} \mathrm{C}$. However, this temperature cannot be achieved while using small sources fuelled with fossil fuels and smaller boiler units of older types with the heat capacity up to $2 \mathrm{MW}$. It happens where combustion products from the combustion area usually flow through the flue or directly through the combustion pipe into the chimney. That is why nitrogen oxides in the combustion products whose temperature in older appliances is below $800{ }^{\circ} \mathrm{C}$ do not originate from the airborne nitrogen but from fuel only. Nitrogen in fossil natural fuel can be found especially in heterocyclic components of compounds and also in wood as proteinaceous residues and amino derivative polysaccharides. There is about $0.7 \%$ of nitrogen in wood, while the occurrence of nitrogen in coal is more variable, usually a bit higher, however, it depends on the locality of mining. That is why the content of nitrogen oxides in the combustion products of coal is usually higher than in the combustion products of wood. The low temperature of the combustion process as well as a short time of flue gas remaining during the combustion of the fossil fuels in the chamber, cause a defective combustion of the gassed fuel. This will result in poor quality of combustion products which can even be visually seen as the presence of a higher portion of soot in combustion products that escape through the chimney into the air, or particularly when analytically evaulating combustion products components. Gaseous combustion products from organic nitrogen are found as nitrogen oxide if the temperature is low. Oxidation of nitrogen oxide materialises only in the atmosphere.

In particular, it is pointed out that there are inappropriate conditions for inlets of primary and secondary air into firing space with regard to the amount of gasified fuel. Inflow of air and directions of its flow are also important. Poor mixing gases in the firing space causes inappropriate combustion, which will give a high content of carbon monoxides as well atmospheric oxygen in different locations of the firing space. At the older low-efficient boilers there is a characteristic short flow distance of combustion gases in the firing

\footnotetext{
* Jozef Blaho ${ }^{1}$, Jozef Víglaský $\dot{2}^{2}$ Peter Horbaj ${ }^{3}$

${ }^{1}$ Faculty of Ecology and Environmental Sciences, Technical University in Zvolen, Kolpašská 9 B., 96901 Banská Štiavnica, Slovak Republic, E-mail: blaho@vsld.tuzvo.sk

${ }^{2}$ Faculty of Environmental and Manufacturing Technology, Technical University in Zvolen, T. G. Masaryka 24, 960 53 Zvolen, Slovak Republic, E-mail: viglasky@vsld.tuzvo.sk

${ }^{3}$ Mechanical Engineering Faculty, Technical University in Košice, Vysokoškolská 4., 04200 Košice, Slovak Republic, E-mail: peter.horbaj@tuke.sk
} 
space, which results in influencing also its good mixing with air in the firing space. It results in a low thermal efficiency, but also in reduced heating value.

Relatively low temperature of fuel gasification as a short time of gassed products remaining in combustion area cause defective combustion. Resulting in dark smoke during such combustion conditions will cause following reactions: there will be an emission of inorganic residues (in the combustion area) along with condensed aromatic organic compounds, often with the content of fixed oxygen that make these inorganic residues visually black. The chemical structure of these substances is very various and also changeable (it depends on conditions of combustion process and combusting fuel) and they are called tarry substances. Many of them belong amongst persistent organic compounds (POC) that are distinguished for their longevity in the atmosphere and their physiological influence on living creatures, also plants and animals is often considered as a carcinogenic, mutagenical, or teratogenic one.

\section{Materials and methods}

Some measurements were undertaken to find out combustion products and their diffusion into the atmosphere from an operation of a boiler unit VSB-4 made in ŽD Bohumín in 1972 with a capacity of $0.25 \mathrm{MWt}$ per hour, working under usual conditions. There is a combustion product ventilator installed in this boiler that is normally used for inundating. The ventilator was not operating during the measurement of the combustion products. During the measurement of emissions and also at usual operation which is carried out only during the winter heating, brown coal type $\mathrm{O}_{2} \mathrm{E}$ with a content of ash $12.5 \%$ and sulphur up to $1 \%$ was used.

The measurement was carried out in a walled flue pipe and places of the measurement were determined according to the rules of STN ISO 10780 [5] and STN ISO 9096 [6]. The flow of the combustion products was calculated from measured physical quantities (dynamic, static and atmospheric pressures, temperature of the combustion products) by Pitot-Prandtl tube and digital micromanometre and density of the combustion products was calculated from the chemical structure of the combustion products (containing oxygen, nitrogen and carbon dioxide, or water vapour). Concentration of combustion gases was calculated from the chemical composition of combustion gases (content of oxygen, nitrogen and carbon dioxin, or water steam).The concentrations of oxygen and carbon oxide were determined by a gas analyser FY IMR 1200 with electrochemical sensors, while carbon dioxide was deducted by analogy. The sulphur oxides were determined by the classical method after sampling into $3 \%$ hydroperoxide according to STN 834711 [9]. The sample of fossil pollutants was taken by Ströhlein apparatus STG 4E and determined by the gravimetric method according to [6]. The qualitative characteristics of fossil emissions was done by determination of a soluble portion of fossil elements in carbon disulphide and the consequential analysis were determined by the gaseous chromatography method of dividing on a capillary column of medium polarity. The programmed change of column temperature was used for separation. The graphic record is presented in Figure 1.

The diffusion of a few volatile organic components (VOC) from a defective combustion of coal was determined according to Szabu programme MODIM $1.20 \mathrm{~d}$ [12].

Within Szabu programme MODIM 1.20 d [12], the author applied methodology of the MLVH (1979) for interpolation of a wind rose.

\section{Results}

The results of concentration and flow of the emissions of basic polluting substances from brown coal combustion in older combustion equipment presented in tables 1-3 are indicated under reference conditions according to the legislative directives [10]. The content of soluble substances from isolated SPM by an organic solvent $\left(\mathrm{CS}_{2}\right)$ was $92.5 \%$, concluding that an average content of inorganic residues in combustion products was $54 \mathrm{mg} \cdot \mathrm{m}^{-3}$. Supposing that during the combustion process while the low temperatures are present, the content of condensed organic substances emitted into the atmosphere of average concentration was $604 \mathrm{~m} . \mathrm{g}^{-3}$, which is emission flow of 531 g.h ${ }^{-1}$ from one boiler. Even if volatile organic compounds (VOC) are not the subjects of evaluation of the combustion product quality according to contemporary applicable legislation, it is interesting to notice their quantity as well as quality arising from the process of an inferior combustion action. The highest concentration of vaporous organic substances of the human breathing zone during average climatic conditions $\left(3.1 \mathrm{~m} . \mathrm{s}^{-1}\right.$ wind speed, $10{ }^{\circ} \mathrm{C}$ air temperature, NE prevailing air circulation) was $10 \mu \mathrm{g} . \mathrm{m}^{-3}$ at a distance of $450-600 \mathrm{~m}$ from the chimney in SW direction during an actual average meteorological situation. The worst concentration of the VOC during unfavourable climatic conditions (calm, stagnation of air layers) is assumed to happen at a distance of 120-320 m from the chimney. In this case the calculated concentration of the VOC in the combustion products was $174 \mu \mathrm{g} . \mathrm{m}^{-3}$. The coefficient "S" used as a criterion for the calculation of minimal height valued at $10 \mu \mathrm{g} \cdot \mathrm{m}^{-3}$ for naphthalene and its derivatives, while toluene and xylene valued $200 \mu \mathrm{g} \cdot \mathrm{m}^{-3}$. These characteristics can be compared with the value of IHk. Owing to the fact that tars from brown coal mainly contain naphthalene and its derivatives, it can be assumed that there is a contravention of imissive limit.

\section{Discussion}

The entrepreneurs of air polluting sources are by laws related to the atmosphere supposed to use BAT (Best Available Technology) when building new mechanisms, i.e. No. 478/2002 [1]. This concept was developed as a directive concerning the atmosphere and known as BATNECC (best available technologies not entailing cost). In the quoted Act the BAT is defined as the best available technology economically achievable, in section $\S 6$, segment 5 . 


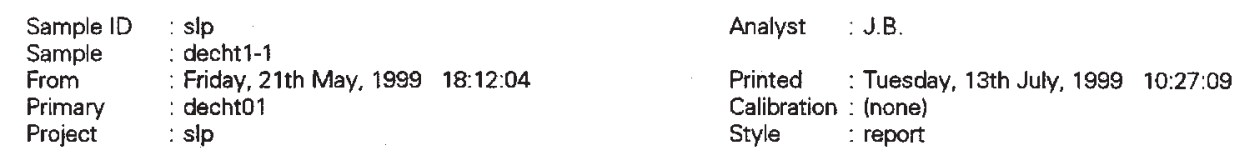

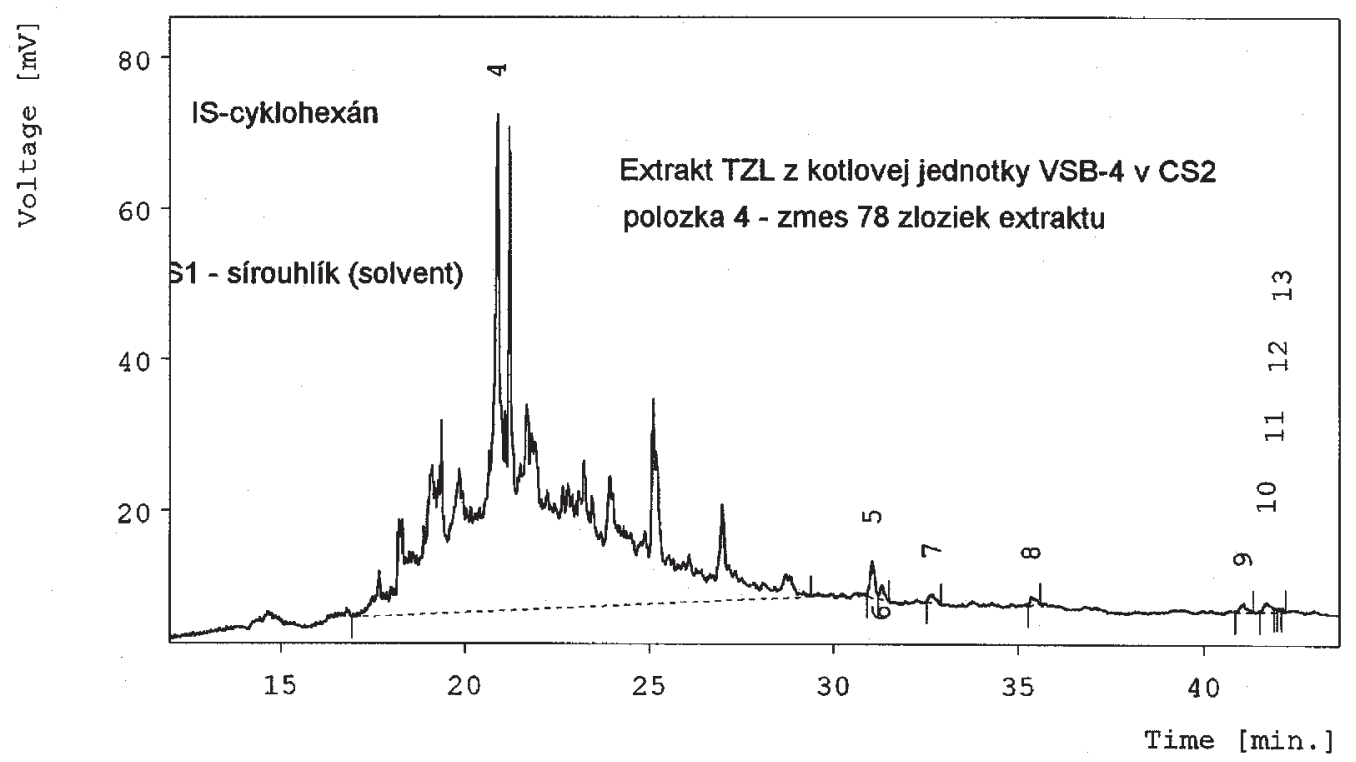

Result Table - Calculation Method Uncal

\begin{tabular}{|r|r|r|r|r|r|r|}
\hline $\begin{array}{l}\text { Peak } \\
\text { No. }\end{array}$ & $\begin{array}{c}\text { Reten. } \\
\text { time }\end{array}$ & $\begin{array}{c}\text { Area } \\
{[\mathrm{mV.s}]}\end{array}$ & $\begin{array}{c}\text { Height } \\
\text { [mV] }\end{array}$ & $\begin{array}{c}\text { W05 } \\
\text { [min.] }\end{array}$ & $\begin{array}{c}\text { Area } \\
{[\%]}\end{array}$ & $\begin{array}{c}\text { Height } \\
\text { [8] }\end{array}$ \\
\hline 2 & 4.147 & 1551.3123 & 679.386 & 0.040 & 17.406 & 89.716 \\
\hline 4 & 20.887 & 7238.4257 & 65.806 & 0.133 & 81.217 & 8.690 \\
\hline 5 & 31.080 & 42.4467 & 4.740 & 0.147 & 0.476 & 0.626 \\
\hline 6 & 31.333 & 15.9550 & 1.931 & 0.120 & 0.179 & 0.255 \\
\hline 7 & 32.700 & 13.8741 & 1.094 & 0.233 & 0.156 & 0.145 \\
\hline 8 & 35.380 & 11.9369 & 1.061 & 0.220 & 0.134 & 0.140 \\
\hline 9 & 41.113 & 14.3074 & 1.097 & 0.180 & 0.161 & 0.145 \\
\hline 10 & 41.760 & 20.3331 & 1.185 & 0.260 & 0.228 & 0.156 \\
\hline 11 & 41.967 & 0.3798 & 0.157 & 0.040 & 0.004 & 0.021 \\
\hline 12 & 42.073 & 1.5540 & 0.341 & 0.087 & 0.017 & 0.045 \\
\hline 13 & 42.180 & 1.8781 & 0.463 & 0.067 & 0.022 & 0.061 \\
\hline- & Total & 8912.4031 & 757.260 & & & \\
\hline
\end{tabular}

Fig. 1 The arrangement of VOC which were isolated from solid particles absorbed on filter during SPM sample take-off by the gas chromatography method applied.

Legend: $\bullet$ IS-cyklohexán: cyclohexane $\bullet S 1$ - sírouhlik: carbon disulphide (solvent) $\bullet$ Extrakt TZL z kotlovej jednotky VSB-4 v CS 2 :

Extract of SPM (Solid Polluting Matters) from VSB-4 boiler unit sample taken from chimney in carbon disulphide (CS 2 )

- Polozka 4 - zmes 78 zloziek extraktu: Item 4 is mixture of 78 components found in an SPM extract.

According to Virčíková [11] the BAT parameters are as follows: emissive limit (or other characteristics if a polluting substance emitted from a source has no emissive limit) + general conditions of operation + technical parameters of operation + precautions to avoid dangerous and accidental

situations + comprehensiveness of air protection solution + security of emissions diffusion + comparability with an air protec- tion standard of developed industrial countries. The BTA criteria are determined by the general obligatory directives dealing with the air protection, technical norms (STN, OTN ŽP, EN, ISO), directives issued by the EU and by the norms of developed countries (e.g. EPA, VDI etc.), and by standard condition of the technology.

The heat production from the fossil fuels, including various kinds of coal, also brings certain obligations for investors in terms 


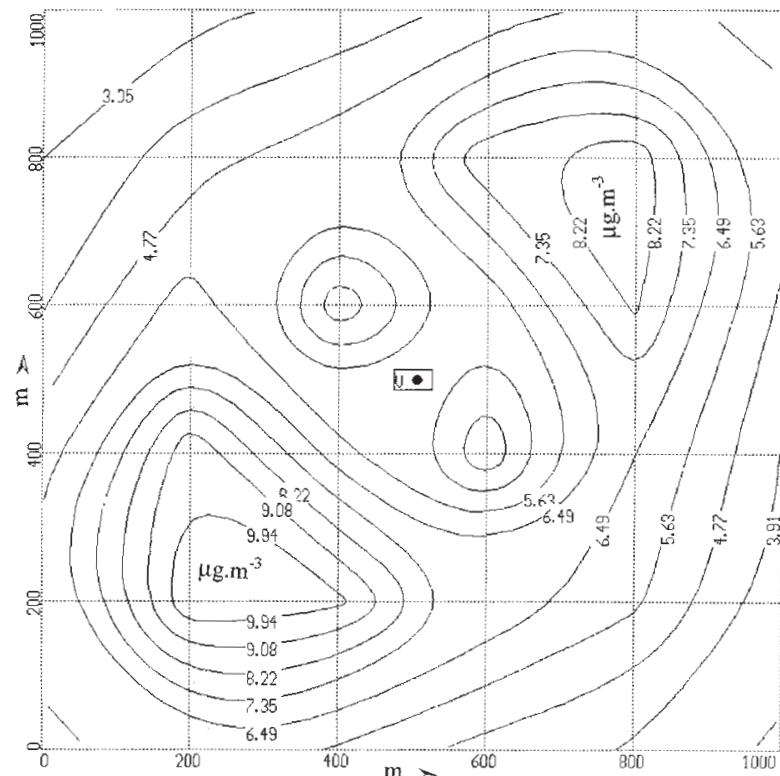

Fig. 2 Isolines of VOC imission concentration gained by brown coal burning technology at low temperature in VSB-4 boiler unit evaluated in the area with average climatic conditions

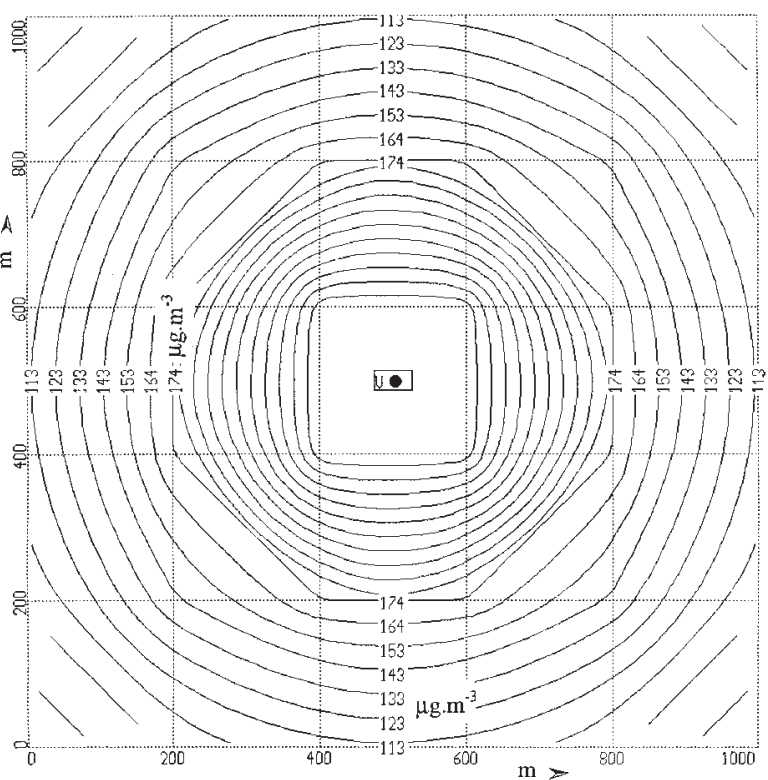

Fig. 3 Isolines of VOC imission concentration in human breathing zone under inclement climatic conditions for their scattering

Concentration and emission flow, emission limits (by reference conditions

Table 1

- $101.325 \mathrm{kPa}, 0{ }^{\circ} \mathrm{C}$ normalised to $6 \%$ oxygen in waste gas).

Fuel: brown coal

\begin{tabular}{|c|c|c|c|c|}
\hline \multirow{2}{*}{ No. } & Polluting mater & \multicolumn{2}{|c|}{ Concentration $\left(\mathrm{mg}_{\mathrm{m}} \mathrm{m}_{\mathrm{r}}\right.$ ) } & \multirow{2}{*}{$\begin{array}{c}\text { Emission } \\
\text { flow }\left(\mathrm{kg} \cdot \mathrm{h}^{-1}\right)\end{array}$} \\
\cline { 3 - 4 } & Somission limit & Measured $\left.{ }^{*}\right)$ & undefined & 0.579 \\
\hline 1. & Solid Polluting Matter (SPM) & 658 & $2500^{1)}$ & 1.2373 \\
\hline 2. & Sulphur Oxide & 1406 & 650 & 0.2358 \\
\hline 3. & Nitrogen Oxides & 268 & Undefined & 2.2792 \\
\hline 4. & Carbon Oxide & 2590 & \\
\hline
\end{tabular}

Explanatory notes: ${ }^{*}$ - results are given as arithmetic average of 12 measurements and analysis from two flue-gas off-takes, 1) - at mass flow $\mathrm{SO}_{2}$ over $20 \mathrm{~kg} / \mathrm{h}$.

Basic statistic characteristics of measured emission source - mass concentration of flue-gas components and volume flow

Table 2 Measurement 1

\begin{tabular}{|c|c|c|c|c|c|c|c|c|}
\hline $\begin{array}{c}\text { Emission } \\
\text { source }\end{array}$ & Measured chara & ics ${ }^{* 1}$ & $\begin{array}{l}\text { Arithmetic } \\
\text { average (x) }\end{array}$ & $\begin{array}{c}\text { Number of } \\
\text { measurements }\end{array}$ & $\begin{array}{c}\text { Maximal } \\
\text { value }\end{array}$ & $\begin{array}{c}\text { Minimal } \\
\text { value }\end{array}$ & $\begin{array}{c}\text { Decisive } \\
\text { deviation }\left(\mathrm{S}_{\mathrm{x}}\right)\end{array}$ & $\begin{array}{c}\text { Error band } \\
\mathrm{L}_{1,2}{ }^{* 2)}\end{array}$ \\
\hline \multirow[t]{5}{*}{ Boiler $\mathrm{K}_{2}$} & \multicolumn{2}{|c|}{ Flow $\left[\mathrm{m}^{3} \cdot \mathrm{h}^{-1}\right]$ (Reference Conditions) } & 882 & 6 & 940 & 838 & 40 & $985-780$ \\
\hline & Concentration SPM & {$\left[\mathrm{mg} \cdot \mathrm{m}^{-3}\right]$} & 972 & 6 & 1063 & 502 & 189 & $1340-380$ \\
\hline & Concentration $\mathrm{SO}_{2}$ & {$\left[\mathrm{mg} \cdot \mathrm{m}^{-3}\right]$} & 1441 & 6 & 1733 & 1103 & 184 & $1913-968$ \\
\hline & Concentration $\mathrm{NO}_{\mathrm{x}}$ & {$\left[\mathrm{mg} \cdot \mathrm{m}^{-3}\right]$} & 238 & 6 & 256 & 205 & 17 & $282-194$ \\
\hline & Concentration $\mathrm{CO}$ & {$\left[\mathrm{mg} \cdot \mathrm{m}^{-3}\right]$} & 3195 & 6 & 3695 & 2420 & 435 & $4313-2007$ \\
\hline
\end{tabular}

Explanatory notes: ${ }^{* 1)}$ under reference conditions (dry gas, $0{ }^{\circ} \mathrm{C}, 101325 \mathrm{~Pa}$, content of $\mathrm{O}_{2}=6 \% \mathrm{~V}$ ). Average temperature of flue-gases in chimney was $54{ }^{\circ} \mathrm{C}$

*2) error band $\mathrm{L}_{1,2}=x \pm t * S_{x}$, where $x$ - arithmetic average, $\mathrm{t}$ - coefficient of Student difference, $S_{x}$ - decisive deviation 
Basic statistic characteristics of measured emission source - mass concentration of flue-gas components and volume flow Measurement 2

\begin{tabular}{|c|c|c|c|c|c|c|c|}
\hline $\begin{array}{c}\text { Emission } \\
\text { source }\end{array}$ & Measured characteristics ${ }^{* 1)}$ & $\begin{array}{l}\text { Arithmetic } \\
\text { average (x) }\end{array}$ & $\begin{array}{c}\text { Number of } \\
\text { measurements }\end{array}$ & $\begin{array}{c}\text { Maximal } \\
\text { value }\end{array}$ & $\begin{array}{c}\text { Minimal } \\
\text { value }\end{array}$ & $\begin{array}{c}\text { Decisive } \\
\text { deviation }\left(\mathrm{S}_{\mathrm{x}}\right)\end{array}$ & $\begin{array}{c}\text { Error band } \\
\mathrm{L}_{1,2}{ }^{* 2)}\end{array}$ \\
\hline \multirow[t]{5}{*}{ Boiler $\mathrm{K}_{2}$} & Flow $\left[\mathrm{m}^{3} \cdot \mathrm{h}^{-1}\right]$ (Reference conditions) & 877 & 6 & 917 & 821 & 30 & $954-800$ \\
\hline & Concentration SPM & 344 & 6 & 410 & 267 & 59 & $462-226$ \\
\hline & Concentration $\mathrm{SO}_{2}$ & 1371 & 6 & 1468 & 1320 & 85 & $1590-1153$ \\
\hline & Concentration $\mathrm{NO}_{\mathrm{x}}$ & 299 & 6 & 359 & 251 & 34 & $386-212$ \\
\hline & Concentration $\mathrm{CO}$ & 1985 & 6 & 2241 & 1827 & 200 & $2500-1471$ \\
\hline
\end{tabular}

Explanatory notes: ${ }^{* 1)}$ under reference conditions (dry gas, $0{ }^{\circ} \mathrm{C}, 101325 \mathrm{~Pa}$, content of $\mathrm{O}_{2}=6 \% \mathrm{~V}$ ). Average temperature of flue-gases in chimney was $65^{\circ} \mathrm{C}$

of legislative norms and statutes. The evaluated apparatus for the heat production - VSB-4 boiler unit determined for the combustion of fossil fuel, according to the BAT requirements, fulfils only requirements concerning emissions limits and their diffusion which are not too strict for low efficiency heating equipment. According to the accomplished measurements it is obvious that the entrepreneur did not achieve the required temperature parameters of combustion products in the chimney, resulting in low temperature of the combustion products in the combustion area of boiler and also defective combustion process resulting in high concentration of carbon dioxide and polluting fossil fuels resulting in SPM (Fig. 1). According to the GC analysis, the character of these organic substances is similar to purposely made tars from brown coal, whose main components are aromatic hydrocarbons, heterocyclic oxygenous, nitrogenous, and sulphuric compounds. Their physiological influence on human and other organisms (e.g. animals, plants etc.) differs in comparison with inorganic compounds of ash. According to figures in tables 2 and 3 it is obvious that higher occurrence of the defective combustion products (carbon dioxide, SPM of organic origin) appears during the low temperature combustion.

Therefore, it is very important for every entrepreneur to respect operational directives and requirements to improve operational quality of the combustion processes and reduce the amount of polluting substances in combustion products that are emitted into the atmosphere $[13,14]$.

\section{Conclusion}

During brown coal combustion at a low temperature, the emissions of polluting substances are emerged and they contain larger amounts of defective combustion products, such as carbonic dioxide and organic gases and vapours of higher aromatic hydrocarbons, heterocyclic compounds and their derivatives, which after refrigeration are transformed into soot-like substances that are soluble in organic solvents. Their amount and qualitative composition depends on the type of combusted coal and conditions of combustion process. During the defective combustion process, the emerging VOCs, pollute the atmosphere, increase the amount of smog in the atmosphere, influence production of ground ozone and they can also cause physiological changes and health problems [15-18].

\section{Acknowledgements}

This research was partly sponsored by grants from the Scientific Grant Agency of Ministry of Education of the Slovak Republic and the Slovak Academy of Sciences, under the contract No. 1/2382/05 VEGA; EC Projects: PN 116441-CP-1-2004-1-FR-MINERVA-M, title: BIO-eTRAIN "The Implementation of an eLearning University for Bioenergy"; Project $N^{\circ}$ : 012429 - BIOPROS "Solutions for the safe application of wastewater and sludge for high efficient biomass production in Short-Rotation-Plantations"; Leonardo da Vinci Project: EnTraCoP - Enhancing the Teaching of Collaborative Planning in Natural Resource Management, the Agreement n² 2005 FI- 05-B-F-PP-160633. Project "FET-EEU" full title: Future Energy Technologies for Enlarged European Union; Proposal/Contract no.: 510417. The authors are greatly indebted to the mentioned institutions for helping to sponsor this research work.

\section{References}

[1] Anonymous: Complete version of the Act No. 478/2002 digest, 20 August 2002, concerning air protection against polluting matters (Act for atmosphere) resulting from later changes and updating (in Slovak)

[2] Regulation of ME of the SR No. 112/1993 digest 27 April 1993, Allocation of areas requiring special air protection, and operation of smog precautionary and control systems in version of later changes and statutes (in Slovak). 
[3] The statute of the government of the SR No. 706/2002 executing the Act No. 478/2002 digest, the Air protection against polluting matter (Act for atmosphere air) in wording of later regulations. In Slovak.

[4] Technical standard OTN ŽP 2002: 96 Air protection. Single-shot measurement of emission and imission polluting surrounding air. Requisites of measurement report (in Slovak).

[5] Slovak technical standard STN ISO 10 780. Stationary sources of polluting. Measurement of speed and volume flow in pipes (in Slovak.)

[6] Slovak technical standard STN ISO 9096. Stationary sources of pollution. Stating of concentration and mass flow of solid polluting matter in flowing gas (in Slovak). Manual gravimetric method.

[7] Uncertainty determination of analytical measurement (in Slovak). Eurachem Slovakia. Bratislava, editted by J. Garaj. 1995 , pp. 96. In Slovak.

[8] BLAHO, J.: Emission of polluting matter generated by VSB-4 boiler brown coal fired (in Slovak). Measurement report, Ekolab Zvolen, 30 p. In Slovak, 1999.

[9] Slovak technical standard 83 4711, the part 1. Measurement of emission: Sulphur Oxide, Sulphuric acid and total sulphur oxide content from polluting air sources (in Slovak).

[10] Regulation No. 41/1997 digest, Quantity determination of polluting matter emitted and data about observance of fixed emission polluting limit (in Slovak).

[11] VIRČÍKOVÁ, E.: Experiences in appraisal of hospital waste incinerators and view of technical possibility of waste processing regarding current interpretation (in Slovak). Proceedings of the conference "Emission Limits". DT ZSVTS Bratislava, pp. 184-191, 1997.

[12] SABÓ, G.: MODIM - calculating programme for imission diffusion (in Slovak). Bulletin of ME of the SR, No. 5, point I.5, 1996.

[13] HORBAJ, P.: Present state of preparation of biofuels from waste and biomass (in Slovak). In: European Commission Directorate General Joint Research Centre, Institute for Energy, CLEANWEB Technical Workshop in collaboration with EU Candidate Countries, Recovered fuels from waste and biomass: Methods of syngas / biofuels / biogas production and cleaning; Fuel utilisation for energy production; 9. - 10. 12. 2003, Bergen, Holandsko http://ie.jrc.cec.eu.int/prewin

[14] FRUHAUFOVÁ, I.: Actualization of environmental regionalization SR - work for ArcView (in Slovak). Enviromagazín, 4/2003, ISSN 1335-1877.

[15] KUNCA, V., 2003: Critical loads of selected forest ecosystems in the Polana Biosphere Reserve (in Slovak). Scientific essay, 4/2003/A, Technical University in Zvolen, pp. 72

[16] KUNCA, V., 2004: Soil resistance against anthropogenic acidification in the Protected Landscape Area - Biosphere Reserve Polana (in Slovak). Acta Facultatis Ecologiae, 12, Technical University in Zvolen, pp. 17-21.

[17] KUNCA, V., ŠTEFFEK, J., OLAH, B., GAVLAS, V., WIEZIK, M., 2005: Dynamics of ecosystems in Štiavnické vrchy Mts (Evaluation from point of view of landscape utilization changes, structure of chosen zoocenosis and forest ecosystem stability). Technical University in Zvolen, pp. 103

[18] KUNCA, V., 2005: Determination of base cations amount released by weathering in forest soils as the one of main parameters in critical loads calculations (in Slovak). Acta Faculta tis Ecologiae, 13, Technical University in Zvolen, pp. 61-69. 